\title{
ASSESSMENT OF EATING AND LIFESTYLE HABITS AMONG POLISH COSMETOLOGY AND PHYSIOTHERAPY STUDENTS
}

\author{
Alicja Szypowska ${ }^{1}$ Małgorzata Jeziorek ${ }^{1}$ Bożena Regulska-Ilow ${ }^{1}$ \\ ${ }^{1}$ Department of Dietetics, Faculty of Health Sciences, Wroclaw Medical University, Poland
}

\begin{abstract}
Background: Proper nutritional behaviors are one of the most important factors shaping our health, as they influence people's physical and mental state. Good eating habits help prevent many chronic diseases, including cardiovascular disease, type II diabetes, some types of cancer, and osteoporosis. The Polish population aged 20-34 years displays improper nutritional behaviors which may put them at risk of developing diet-dependent diseases in the future. There is a need to assess students' lifestyle, including their eating habits, as it would help adapt already existing education programs.

Objective. We evaluated and compared eating habits and lifestyle of students studying cosmetology and physiotherapy in association with selected risk factors of civilization diseases.

Material and methods. We used a standardized dietary questionnaire evaluating respondents' physical activity, smoking and dietary habits. The obtained results were compared with the recommendations from the Polish food-based dietary guidelines. We evaluated respondents' nutritional status based on their anthropometric measurements such as body weight, body height, hips and waist circumferences and then we estimated their body mass index (BMI) and waist hip ratio (WHR). Results. Students studying cosmetology and physiotherapy obtained on average $5.3 \pm 1.5$ points based on their compliance with the nutritional recommendations. The academic youth did not meet principles of healthy nutrition according to the given recommendations. There were no significant differences in nutrition status between the faculties, except for products that provide complete protein.

Conclusions. There is a need to increase nutritional awareness of academic youth, especially students of health-related faculties, because better knowledge on nutrition would help them choose healthier food options.
\end{abstract}

Key words: dietary habits, nutritional mistakes, cosmetology, physiotherapy

\section{STRESZCZENIE}

Wprowadzenie: Prawidłowe zwyczaje żywieniowe są jednym z ważniejszych czynników kształtujących zdrowie, ponieważ wpływają na właściwy stan fizyczny i psychiczny. Wskazuje się na korzystną rolę żywienia w profilaktyce wielu chorób przewlekłych, takich jak choroby układu krążenia, cukrzycy typu 2, niektórych nowotworów oraz osteoporozy. Wykazano, że wśród populacji polskiej w wieku 20-34 lat występują niewłaściwe zachowania żywieniowe, co może w przyszłości prowadzić do rozwoju chorób dietozależnych. Istnieje potrzeba oceny elementów stylu życia, w tym zwyczajów żywieniowych, młodzieży akademickiej w celu dostosowania odpowiednich programów edukacyjnych.

Cel. Celem badania była ocena i porównanie zwyczajów żywieniowych oraz elementów stylu życia studentów Fizjoterapii i Kosmetologii, w kontekście występowania wybranych czynników ryzyka chorób cywilizacyjnych.

Materiał i metody. Ocena zwyczajów żywieniowych została przeprowadzona z użyciem metody ankietowej. Narzędziem badawczym był wystandaryzowany kwestionariusz diety, dotyczący wskaźnika aktywności fizycznej, statusu palenia papierosów oraz zwyczajów żywieniowych. Uzyskane wyniki porównano z rekomendacjami zawartymi w Złotej Karcie Prawidłowego Żywienia. Oceny stanu odżywienia dokonano na podstawie pomiarów antropometrycznych takich jak: masa i wysokość ciała, obwody bioder i talii, a następnie oszacowano wartość wskaźnika BMI (body mass index) oraz wskaźnika WHR (waist hip ratio).

Wyniki. Średnia liczba punktów uzyskanych na podstawie zgodności deklarowanego sposobu żywienia studentów z za-

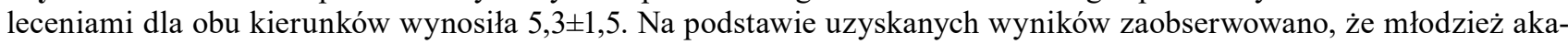
demicka nie realizowała zasad zdrowego żywienia zgodnie z rekomendacjami. Nie odnotowano istotnych różnic w przestrzeganiu zasad żywienia między poszczególnymi kierunkami studiów, za wyjątkiem spożycia produktów będących źródłem pełnowartościowego białka.

Wnioski. Właściwe zwyczaje żywieniowe stanowią istotny element profilaktyki chorób dietozależnych, dlatego istnieje potrzeba zwiększania świadomości żywieniowej młodzieży akademickiej, szczególnie na kierunkach związanych ze zdrowiem, ponieważ wyższy poziom wiedzy sprzyja propagowaniu prozdrowotnych zachowań.

Slowa kluczowe: nawyki żywieniowe, błędy żywieniowe, kosmetologia, fizjoterapia

Corresponding author: Małgorzata Jeziorek, Department of Dietetics, Faculty of Health Sciences, Wroclaw Medical University, Parkowa street 34, 51-616 Wroclaw, Poland, tel. +48 713483531 , e-mail: malgorzata.jeziorek@umed.wroc.pl

(C) Copyright by the National Institute of Public Health - National Institute of Hygiene 


\section{INTRODUCTION}

Proper eating habits are one of the most important factors shaping people's health, as they affect proper physical and mental state, good memory, our ability to learn and good appearance. Studies have confirmed the influence of a well-balanced diet on human health [5, $8,16]$. Experts point to the beneficial role of nutrition in the prevention of many chronic diseases such as cardiovascular disease, type 2 diabetes, certain types of cancer, osteoporosis and osteopenia. Dietary habits determine our quality of life and longevity $[5,8,16]$. Authors of the WOBASZ study demonstrated that the Polish population aged 20-34 years had improper dietary behaviors, which may lead to the development of diet-related diseases in the future [18]. The above observations indicate the need to assess eating habits of academic youth in order to adapt existing education programs. Some authors found a link between the answers provided by the students of medical faculties in the questionnaire regarding their eating habits and the declared knowledge on the principles of proper nutrition. Improper eating habits of students from non-medical faculties were associated with snacking, low consumption of vegetables and legumes, high consumption of sweets, ready-made meals, sugar and alcohol. The above data indicates that dietary behaviors of the studied academic youth were unsatisfactory [9]. Apart from dietary habits, smoking, alcohol consumption and low levels of physical activity are important elements of health. Due to irregular lifestyle, high levels of stress and leaving the family home, students are more likely to make bad dietary choices and they start taking stimulants [8, 12].

We evaluated and compared eating habits and elements of lifestyle of students studying physiotherapy and cosmetology from Wroclaw universities with regard to selected risk factors of civilization diseases.

\section{MATERIAL AND METHODS}

We assessed eating habits of 121 cosmetology and 44 physiotherapy students using a standardized diet questionnaire containing 45 questions about respondents' personal data, lifestyle (physical activity, smoking) and eating habits. The obtained results were compared with the recommendations from the Polish food-based dietary guidelines [19]. To evaluate respondents' eating habits, we gave them 1 or 0 points depending on how they implemented recommendation from the Polish food-based dietary guidelines. The average number of points showed respondents' compliance with the recommendations. The points ranged from 0 to 1.1 point was awarded if students met 1 recommendation from the guidelines. We summed up all points. We gave 0 points if the declared answer did not comply with the recommendations. The nutritional status of academic youth was assessed on the basis of anthropometric measurements such as body weight, body height, hips and waist circumferences. We also estimated their body mass index (BMI) and waist hip ratio (WHR).

All data was analyzed using STATISTICA v.10.0 PL software (StatSoft Inc., USA). The obtained results were verified using Chi-square tests (two variables), cross-tabulation analysis (three variables), and Mann Whitney $\mathrm{U}$ test.

\section{RESULTS}

The study group included $99.2 \%$ women studying cosmetology and $59.1 \%$ women studying physiotherapy. The average age of the study participants was $21.8 \pm 4.6$ years and the average value of their BMI was $22.4 \pm 3.5$. However, physiotherapy students had significantly higher BMI as compared to cosmetology students. The percentage of adipose tissue was similar in both groups. Significantly more cosmetology students smoked or had smoked in the past as compared to physiotherapy students (41.3 vs. 22.7 ; $\mathrm{p}=0.0281$ ). Students of cosmetology declared lower physical activity than students of physiotherapy. More than half of physiotherapy students $(65.9 \%)$ declared moderate or vigorous physical activity (20-60 min, 2-7 times a week). More cosmetology students took dietary supplements as compared to physiotherapy students. Cosmetology students admitted taking vitamin D (35.5\%), magnesium (19.0\%), B-vitamins complex (17.4\%), the vitamin A and E complex (15.7\%) and horsetail (14.1\%). Physiotherapy students most often declared taking vitamin D (43.2\%), magnesium (36.4\%), B-vitamins complex (20.5\%), and vitamins $\mathrm{A}$ and $\mathrm{E}(18.2 \%)$. The characteristics of the studied group are presented in Table 1 .

We evaluated students' eating habits using a standardized dietary questionnaire. The obtained results were compared with the recommendations from the Polish food-based dietary guidelines and are presented in Table 2. The average number of points obtained by students of both faculties based on their compliance with recommendations was $5.3 \pm 1.5$ (5.3 \pm 1.4 for cosmetology students and $5.4 \pm 1.7$ for physiotherapy students). Based on the obtained results, we concluded that students did not follow the rules of proper nutrition according to the recommendations from the Polish food-based dietary guidelines.

We reported no significant differences between the 2 studied faculties in terms of following the rules of proper nutrition, except for consuming products that provide complete protein. Significantly more cosmetology students $(92.6 \%)$ consumed at least 1 serving of fish, peas, beans or meat daily as compared 
Table 1 . Characteristics of the study group $(n=165)$

\begin{tabular}{|l|c|c|c|c|}
\hline \multicolumn{1}{|c|}{ Variable } & $\begin{array}{c}\text { Total } \\
(\mathrm{n}=165)\end{array}$ & $\begin{array}{c}\mathrm{C} \\
(\mathrm{n}=121)\end{array}$ & $\begin{array}{c}\mathrm{P} \\
(\mathrm{n}=44)\end{array}$ & $\begin{array}{c}\text { C vs P } \\
\mathrm{p} \text {-value }\end{array}$ \\
\hline Age [years] & $21.8 \pm 4.6$ & $20.8 \pm 2.3$ & $24.8 \pm 7.4$ & $\mathrm{p}<0.0001$ \\
\hline Women [\%] & 88.5 & 99.2 & 59.1 & $\mathrm{p}<0.0001$ \\
\hline BMI [kg/m²] & $22.4 \pm 3.5$ & $21.8 \pm 3.3$ & $23.9 \pm 3.8$ & $\mathrm{p}=0.0001$ \\
\hline WHR & $0.7 \pm 0.1$ & $0.7 \pm 0.1$ & $0.8 \pm 0.1$ & $\mathrm{p}=0.0195$ \\
\hline Body fat [\%] & $24.5 \pm 8.2$ & $24.9 \pm 8.5$ & $23.3 \pm 7.3$ & $\mathrm{p}=0.2347$ \\
\hline Smoking [\%] & 36.4 & 41.3 & 22.7 & $\mathrm{p}=0.0281$ \\
\hline Low physical activity [\%] & 59.4 & 68.6 & 34.1 & $\mathrm{p}=0.0001$ \\
\hline Taking supplements & 35.2 & 38.9 & 25.0 & $\mathrm{p}=0.0996$ \\
\hline
\end{tabular}

$\mathrm{C}$ - cosmetology; P - physiotherapy; BMI - body mass index; WHR - waist hip ratio; $\mathrm{p}<0.05$ - statistically significant values.

Table 2. The compliance of the diet with the recommendations from the Polish food-based dietary guidelines

\begin{tabular}{|c|c|c|c|}
\hline $\begin{array}{l}\text { Recommendations from the Polish food-based } \\
\text { dietary guidelines }\end{array}$ & $\begin{array}{c}\mathrm{C} \\
\text { percentage of } \\
\text { respondents meeting the } \\
\text { recommendations } \\
{[\%]}\end{array}$ & $\begin{array}{c}\mathrm{P} \\
\text { percentage of respondents } \\
\text { not meeting the } \\
\text { recommendations } \\
{[\%]}\end{array}$ & $\begin{array}{l}\text { C vs P } \\
\text { p-value }\end{array}$ \\
\hline $\begin{array}{l}\text { At least } 3 \text { meals daily of moderate size - } \\
\text { including breakfast }\end{array}$ & 84.3 & 94.5 & 0.0572 \\
\hline $\begin{array}{l}\text { Grains with each meal (dark bread, flakes, } \\
\text { groats, pasta or potatoes) }\end{array}$ & 8.3 & 13.6 & 0.3025 \\
\hline $\begin{array}{l}\text { Fruits and vegetables (fresh or frozen) with each } \\
\text { meal and as snacks }\end{array}$ & 55.4 & 61.4 & 0.4918 \\
\hline $\begin{array}{l}\text { At least } 2 \text { glasses of milk (preferably lean) or } \\
\text { the same amount of kefir and yoghurt and } 1-2 \\
\text { slices of cheese }\end{array}$ & 7.4 & 4.6 & 0.5101 \\
\hline $\begin{array}{l}\text { One serving of fish, peas, beans or meat (lean, } \\
\text { preferably poultry) }\end{array}$ & 92.6 & 79.6 & 0.0177 \\
\hline One tablespoonful of vegetable or olive oil & 44.6 & 50.0 & 0.5404 \\
\hline $\begin{array}{l}\text { At least } 1 \text { liter of mineral water and natural } \\
\text { fruit and vegetable juice (with no added sugar) }\end{array}$ & 79.3 & 84.1 & 0.4948 \\
\hline Avoiding excess salt & 39.7 & 43.2 & 0.6845 \\
\hline Avoiding excess sugar & 52.1 & 45.5 & 0.4525 \\
\hline Avoiding excess alcohol & 61.2 & 65.9 & 0.5773 \\
\hline
\end{tabular}

$\mathrm{C}$ - cosmetology; $\mathrm{P}$ - physiotherapy; $\mathrm{p}<0.05$ - statistically significant values.

to physiotherapy students $(79.6 \%)$. The recommended intake of fish is 1-2 servings per week. About one fifth of the students consumed fish as recommended, but the rest did it irregularly. The preferred methods of cooking fish were roasting (49.5\%) and frying (33.3\%).

The majority of students did not eat whole grains with every meal $(91.7 \%$ of cosmetology students; $86.4 \%$ of physiotherapy students). $47.5 \%$ of students declared daily consumption of refined grains with two meals. Refined grains are not recommended due to their low dietary fiber content, high glycemic index, and high level of processing.

More than half of the students consumed vegetables and fruits with every meal $(55.4 \%$ of cosmetology students; $61.4 \%$ of physiotherapy students). The average number of fruit servings was $1.8 \pm 1.3$, and the average number of vegetable servings was $2.0 \pm 1.3$. Therefore, the intake of fruits and vegetables was inadequate.

We reported improper intake of milk and dairy products in the studied participants. $92.6 \%$ of cosmetology and $95.4 \%$ of physiotherapy students did not follow recommendations regarding consumption of this food group. Almost half (49.5\%) of the respondents did not consume milk, kefir, yoghurt or they did it irregularly. About $30 \%$ of the students declared that they consumed 1-2 slices of cheese daily, and $52.7 \%$ of the respondents did not consume cheese 
at all or did it only occasionally. The recommended number of milk group servings is at least 2 glasses of milk and 1-2 slices of cheese daily. Milk and dairy products are the main source of calcium in the diet, which is a key mineral for building peak bone mass in adolescence.

Half of the studied participants did not follow the recommendation for consuming vegetable oils $(55.4 \%$ of cosmetology students; $50.0 \%$ of physiotherapy students). The most frequently chosen cold vegetable fat was olive oil (74.2\%) and the least frequently chosen oil was the linseed oil (4.3\%). Butter was chosen mainly to spread on bread (71.0\%), but some students used it for frying (23.7\%). Moreover, rapeseed, sunflower and coconut oil were chosen for frying $(52.7 \%, 36.6 \%$ and $22.6 \%$ respectively). The analysis of the data shows that students' diets lack recommended vegetable fats.

The majority of respondents met recommendation for drinking mineral water and natural fruit or vegetable juices (79.3\% cosmetology; $84.1 \%$ physiotherapy). The recommended daily water intake is at least 1 liter.

The studied participants did not meet the recommendations for avoiding excess salt and sugar in the diet. Almost half (49.7\%) of the respondents added sugar to their daily drinks. Average sugar consumption in the study group was $12.2 \mathrm{~g} \pm 17.6$.

About $40 \%$ of students declared to consume alcohol once a week or more. The most frequently chosen alcohol was wine and beer (47.5\%; 37.6\%).

Preferences concerning the purchase and consumption of particular food products due to their fat content are presented in Table 3. More respondents consumed reduced-fat than full-fat dairy. However, $44.3 \%$ of respondents did not care about the fat content in meat and meat products.

Most of the respondents consumed 3 main meals a day, including breakfast (breakfast $-62.6 \%$, lunch - $76.5 \%$, dinner - $61.7 \%$ ). $32.2 \%$ of responders had daily snacks between meals. Sweet and salty snacks such as: bars, cakes, wafers, sweet buns, yeasts, chips, sticks, crackers $(86.1 \%)$ were the most popular. Fruit and/or vegetables were chosen by $67 \%$ of the respondents, and dairy products such as kefir, buttermilk, milk drinks, yoghurt were consumed by $38.3 \%$ of the respondents. Students did not regularly eat second breakfast or the afternoon tea snack. The frequency of consuming particular meals during the day is presented in Figure 1.

\section{DISCUSSION}

We assessed elements of lifestyle, including eating habits, in students of medical (physiotherapy) and nonmedical faculties (cosmetology). The overall result of the study was unsatisfactory. Based on the above observations, we concluded that there is a need of educating and shaping appropriate pro-health attitudes among academic youth. Students of physiotherapy will become medical personnel and they should, as well as students of cosmetology, pay attention to the quality of nutrition to maintain proper condition of

Table 3. The percentage of respondents consuming particular food products due to their fat content

\begin{tabular}{|l|c|c|c|c|}
\hline \multicolumn{1}{|c|}{ Category } & $\begin{array}{c}\text { Milk } \\
{[\%]}\end{array}$ & $\begin{array}{c}\text { Yoghurt } \\
{[\%]}\end{array}$ & $\begin{array}{c}\text { Quark } \\
{[\%]}\end{array}$ & $\begin{array}{c}\text { Meat, cold meats } \\
{[\%]}\end{array}$ \\
\hline I always choose low-fat foods & 39.1 & 16.5 & 23.5 & 28.7 \\
\hline I consume low- and high-fat foods & 27.8 & 31.3 & 31.3 & 23.5 \\
\hline I always choose high-fat foods & 9.6 & 6.1 & 5.2 & 0.8 \\
\hline I do not care & 13.9 & 41.7 & 33.9 & 44.3 \\
\hline I do not eat them at all & 9.6 & 4.3 & 6.1 & 3.5 \\
\hline
\end{tabular}

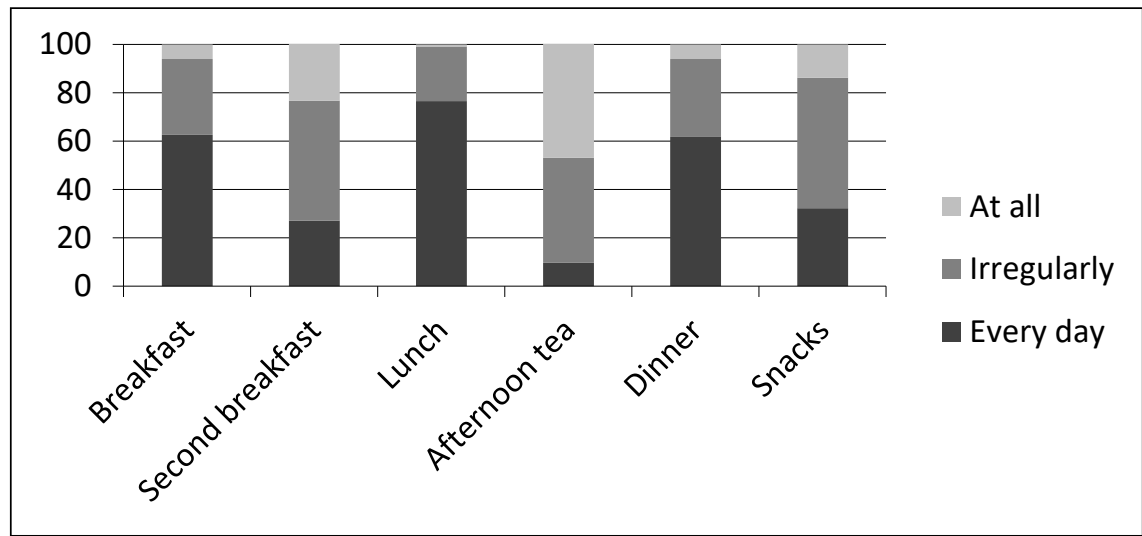

Figure 1. Percentage of people eating particular meals during the day 
their bodies, skin and general appearance. Students of these faculties should know the importance of healthseeking behaviors in the context of disease prevention, as they will soon play a significant role in promoting the principles of healthy lifestyle. This has already been indicated by other authors $[1,15]$.

Kłos et al. [5] reported that the average value of the BMI in students from the Józef Piłsudski University of Physical Education in Warsaw was $23.4 \pm 2.6 \mathrm{~kg}$ / $\mathrm{m}^{2}$. However, in the study by Kaźmierczak et al. [4] conducted in the students from Poznan, the BMI was $21.7 \pm 2.96 \mathrm{~kg} / \mathrm{m}^{2}$ in female and $24.1 \pm 3.31 \mathrm{~kg} / \mathrm{m}^{2}$ in male students. In our study, the average BMI of respondents was $22.4 \pm 3.5 \mathrm{~kg} / \mathrm{m}^{2}$, which is within the normal reference range. However, we noted significant differences in BMI values between the studied faculties (cosmetology $21.8 \pm 3.3$ vs. physiotherapy $23.9 \pm 3.8$ ). On the other hand, other authors found no differences in the BMI among students of medical (nursing) and non-medical (economy) faculties from the Świętokrzyskie Voivodeship [9]. Kowalik et al. [6] demonstrated that more than half of the surveyed students took dietary supplements, mainly vitamins or minerals. Students used dietary supplementation because they wanted to boost their immune systems, strengthen their nails or hair, or improve their skin. In our study, $35.5 \%$ of the respondents declared taking dietary supplements, of which the majority studied cosmetology. The most commonly taken supplements were magnesium, B-vitamins complex, the vitamin A and E complex, and horsetail, which is probably related to the specificity of the faculty.

Regular physical activity is an important element of healthy lifestyle as it prevents overweight and obesity - the major causes of civilization diseases [14]. Snopek et al. [14] demonstrated that $31.7 \%$ of medical students declared low physical activity, whereas the majority of medical students declared moderate physical activity. Low physical activity was defined as physical exercises for 20-60 min once a week or less. Physiotherapy students showed significantly higher physical activity than cosmetology students. $65.9 \%$ of physiotherapy students declared moderate or high physical activity, which is probably related to the specificity of their faculty. Cosmetology students significantly more often declared smoking, which is a significant risk factor for cardiovascular diseases, than physiotherapy students ( $41.3 \%$ vs. $22.7 \%$ ). On the other hand, in the study by Snopek et al. [14], smoking was declared only by $13.3 \%$ of respondents.

The Polish food-based dietary guidelines recommends eating at least 3 moderate-size meals daily and not skipping breakfast. Eating only 2 or 1 meals per day is associated with more frequent snacking and inappropriate dietary choices. In our study most of the respondents met the recommendation regarding the number of daily meals $(84.3 \%$ of cosmetology and $94.5 \%$ of physiotherapy students). Other authors reported that $100 \%$ of students of Józef Piłsudski University of Physical Education in Warsaw declared to consume at least 3 meals a day [5]. GawlikowskaSroka et al. [2] demonstrated that only $50 \%$ of medical students regularly ate 3 meals a day, whereas about $1 / 3$ of the respondents ate between meals, usually snacks of low nutritional value. Orkusz et al. [13] demonstrated that almost $90 \%$ of American and Australian students consumed snacks. American students most often chose fast-food products and Australian students fruits. Our results showed that the majority of Polish students chose unhealthy snacks.

Whole grains are a healthy diet staple and should be eaten with every meal [8]. In our study, only $8.3 \%$ of cosmetology and $13.6 \%$ of physiotherapy students met this recommendation. However, in the other study carried out in medical students, $1 / 3$ of respondents consumed whole wheat bread [2]. Different results were obtained in the study evaluating dietary behaviors of women studying in Warsaw at the Józef Piłsudski University of Physical Education and Warsaw University of Life Sciences, where the whole grains consumption was declared respectively, by $62 \%$ and $78 \%$ of respondents [11]. Our results demonstrated that the intake of carbohydrates, including dietary fiber, was too low.

A minimum consumption of $400 \mathrm{~g}$ of fruits and vegetables per day significantly reduces the risk of ischemic heart disease and arterial hypertension [3]. Vegetables and fruits are the main source of antioxidants, polyphenols and dietary fiber (especially from the water-soluble fraction). Vegetables and fruits are low in calories and produce a small increase in postprandial blood glucose, which further increases their protective potential against civilization diseases [3]. The study carried out in students of Wroclaw Medical University found insufficient consumption of vegetables and fruits. Ilow et al. [3] demonstrated that $62 \%$ of female and $75 \%$ of male students consumed less than 5 servings of vegetables and fruits per day. Walentukiewicz et al. [17] noted insufficient consumption of vegetables and fruits in $60 \%$ of students from the Gdansk University of Physical Education and Sport. In our study, almost half of the studied respondents did not meet the recommendations concerning the daily consumption of fruits and vegetables. Students consumed comparable number of fruit and vegetables.

We observed that the majority of respondents did not meet the recommendation regarding the intake of milk and dairy. Over $90 \%$ of cosmetology and physiotherapy students did not consume enough servings of dairy, including cheese. This fact is worrying since milk and dairy are a valuable source 
of well-assimilated calcium, wholesome protein, and fat-soluble vitamins [10]. Malczyk et al. [8] obtained similar results and demonstrated that students from Opole, Silesia and Lower Silesia universities consumed milk once or several times a week. Moreover, very low milk consumption was reported by Ilow et al. [3], who showed that $23.1 \%$ of female students and $26.1 \%$ of male students consumed the recommended number of dairy servings per day. Misiarz et al. [9] reported sufficient consumption of dairy in students of medical and non-medical faculties from the Świętokrzyskie Voivodeship. However, other authors who analyzed eating habits of students from Wroclaw University of Economics obtained different results. In their study over $40 \%$ of respondents declared to consume milk at least once a day [7]. Data analysis showed that the consumption of milk and dairy in academic youth is becoming less popular which is not in line with the dietary recommendations from the Polish food-based dietary guidelines.

We found that half of the surveyed students added sugar to their coffee or tea. Ilow et al. [3] reported similar results. In their study, about $60 \%$ of students added sugar to drinks, and the average consumption of added sugar was $24.7 \mathrm{~g}$ /day among female and $30.8 \mathrm{~g} / \mathrm{day}$ among male students of Wroclaw Medical University. In our own study the average consumption of added sugar was $12.2 \pm 17.6 \mathrm{~g} /$ day.

Since proper nutritional behaviors are an important part of preventing diet-related diseases, there is a need to increase nutritional awareness in academic youth, especially in students of health-related faculties, because if they had better knowledge they would seek healthy dietary options.

\section{Conflict of interest}

The authors declare no conflict of interest.

\section{REFERENCES}

1. Baumgart M., Weber-Rajek M., Radzimińska A., Goch A., Zukow $W$ : Z Zachowania zdrowotne studentów fizjoterapii. [Health behaviors of students of Physiotherapy]. J Educ Health Sport 2015;5(6): 211-224 (in Polish).

2. Gawlikowska-Sroka A., Dzięciołowska-Baran E., Szczurowski J:: Ocena nawyków żywieniowych studentów polskich pierwszego roku medycyny [Evaluation of the dietary habits of Polish medical students in their first year of studies]. Pom J Life Sci. 2015;61(2):186-190 (in Polish).

3. Ilow R., Regulska-Ilow B., Różańska D.: Dietary habits of Wroclaw Medical University students (Poland). Rocz Panstw Zakl Hig 2017;68(1):23-32.

4. Kaźmierczak A., Bolestawska I., Główka A., Dzięciol M., Przystawski J.: Ocena wybranych parametrów antropometrycznych wśród młodzieży akademickiej
Poznania [An evaluation of the selected anthropometric parametrs among students in Poznan]. Bromat Chem Toksykol. 2012;45(3):1099-1104 (in Polish).

5. Kłos A., Tomczak A., Kłos K., Kęska A., Bertrandt J.: Ocena stanu odżywienia oraz zachowań żywieniowych studentów akademii wychowania fizycznego Józefa Piłsudskiego w Warszawie [Assessment of nutritional status and nutritional behavior of students of the Józef Piłsudski University of Physical Education in Warsaw and its satellite in Biała Podlaska]. Bromat Chem Toksykol. 2016;49(2):138 -144 (in Polish).

6. Kowalik M., Mendyk K.B., Klimek M., Antos-Latek K., Pagacz K., Lewicki M., Obel E.: Popularność oraz powody stosowania suplementów diety w populacji studentów w wieku 19-26 lat. [The popularity and the reasons for the use of dietary supplements among the student population aged 19-26 years]. Piel Zdr Publ. 2016;6(4):295-299 (in Polish).

7. Kowalska A.: Mleko i przetwory mleczne w diecie studentów Uniwersytetu Ekonomicznego we Wrocławiu [Milk and milk products in the diet of students at the University of Economics in Wroclaw]. Roczniki Naukowe. 2014;16(1):111-116: (in Polish).

8. Malczyk E., Zołoteńka-Synowiec M., Całyniuk B., Malczyk A., Synowiec J.: Częstotliwość spożycia wybranych produktów spożywczych przez studentów opolskich, śląskich i dolnośląskich uczelni [The frequency of consumption of selected food products by students from Opole Voivodship, Lower Silesia and Silesian universities]. Piel Zdr Publ. 2017;26(1):35-43: (in Polish). DOI 10.17219/pzp/66330

9. Misiarz M., Malczyk E., Zołoteńka-Synowiec M., Rydelek J., Sobota O.: Ocena zachowań żywieniowych studentów kierunków medycznych i niemedycznych z województwa świętokrzyskiego [Assessment of dietary behaviors of students the medical and nonmedical Świętokrzyskie voivodeship]. Piel Zdr Publ. 2013;3(3):265-272: (in Polish).

10.Mojka K.: Charakterystyka mlecznych napojów fermentowanych [Characteristics of fermented milk drinks]. Probl Hig Epidemiol. 2013;94(4):722-729 (in Polish).

11. Myszkowska-Ryciak J., Kraśniewska A., Harton A., Gajewska D.: Porównanie wybranych zachowań żywieniowych studentek Akademii Wychowania Fizycznego i Szkoły Głównej Gospodarstwa Wiejskiego w Warszawie [Comparison of selected nutritional behaviors of female students of the University of Physical Education and of the University of Life Sciences in Warsaw]. Probl Hig Epidemiol. 2011;92(4):931-934: (in Polish).

12.Nieradko-Iwanicka B.: Ocena stanu odżywienia studentów II roku I Wydziału Lekarskiego z Oddziałem Stomatologii Uniwersytetu Medycznego w Lublinie badanie pilotażowe [Nutritional assessment of the IIyear students of Medical Faculty with Dentistry Division of Medical University in Lublin - pilot study]. Fam Med Prim Care Rev. 2014;16(2):138-139 (in Polish).

13. Orkusz A., Janczar-Smuga M.: Ocena zwyczajów żywieniowych studentów polskich, amerykańskich i australijskich [Assessment of eating habits of polish, 
american and australian students]. Zeszyty Problemowe Postępów Nauk Rolniczych. 2016;586:147-156 (in Polish).

14. Snopek S., Szostak-Wegierek D., Ziółkowska A.: Rozpowszechnienie cech stylu życia zwiększających ryzyko zaburzeń lipidowych u młodych mężczyzn - studentów medycyny [Prevalence of lifestyle characteristics increasing the risk of lipid disorders in young male medical students]. Probl Hig Epidemiol 2009;90(4): 598-603 (in Polish).

15. Sochacka L., Wojtylko A.: Aktywność fizyczna studentów studiów stacjonarnych kierunków medycznych i niemedycznych [Physical activity students of the medical and non-medical degree courses]. Environmental Medicine. 2013;16(2):53-58 (in Polish).

16. Stefańska E., Ostrowska L., Czapska D. Karczewski $J .:$ Wartość odżywcza posiłków w dietach kobiet o prawidłowej i nadmiernej masie ciała [Nutritional value of meals in the diets of women with normal and excessive body weight]. Rocz Panstw Zakl Hig 2010;61(2):201-205 (in Polish).
17. Walentukiewicz A., Łysak A., Wilk B.: Ocena sposobu żywienia studentów w kontekście profilaktyki chorób cywilizacyjnych [Assessment of students' nutrition in context of prevention of civilization diseases]. Probl Hig Epidemiol. 2014;95(3):772-777: (in Polish).

18. Waśkiewicz A.: Jakość żywienia i poziom wiedzy zdrowotnej u młodych dorosłych Polaków - badanie WOBASZ. [Quality of nutrition and level of health knowledge in young adult Polish population - the WOBASZ project]. Probl Hig Epidemiol. 2010;91(2): 233-237 (in Polish).

19. Złota Karta Prawidłowego Żywienia. [The Polish foodbased dietary guidelines]. Czyn Ryz. 1997;17-18, 7a: (in Polish).

Received: 06.02.2020

Accepted: 06.04.2020 